\title{
REFORM OF THE SYSTEM OF EDUCATION IN PESANTREN
}

\author{
Erniati \\ Universitas Islam Negeri Alauddin (UIN) Makassar \\ Jl. Sultan Alauddin No. 63 Makassar \\ Email: erni_Labuaja@yahoo.co.id
}

\begin{abstract}
Abstrack. Impact of pesantren education system update can be viewed in terms of its negative and positive aspects. The negative side, schools that still persists in the form of salafiless able to again growConduciveand schools that have been developed into a boarding Khalafihave started to tend to the economic orientation that has implications for the values of sincerityless. While the positive impact schools have the ability to survivein the midst of change and competition continues to run, has the ability to improve its quality, and has the ability to evolve and adapt to the ever-changing era guidance. The challenges facing the education system reform schools, namely the challenge of macro and micro. At the macro level schools are challenged to work on institutional Triumvirate, namely the family, workplace, and schools themselves. While the micro, schools are required to rearrange the interaction between students and Kiai, the concept of education, and the curriculum used.
\end{abstract}

Abstrak. Dampak pembaruan sistem pendidikan pesantren dapat dilihat dari segi negatifnya dan segi positifnya. Dari segi negatifnya, pesantren yang masih bertahan dalam bentuk salafi kurang mampu lagi berkembang secara kodusif dan pesantren yang sudah berkembang menjadi pesantren khalafi sudah mulai cenderung kepada orientasi ekonomis sehingga berimplikasi pada nilai-nilai keikhlasan yang kurang. Sementara danpak positifnya adalah pesantren memiliki kemampuan untuk survive di tengah-tengah perubahan dan persaingan yang terus bergulir, memiliki kemampuan untuk meningkatkan kualitasnya, serta memiliki kemampuan untuk berkembang dan beradaptasi dengan tuntunan zaman yang terus berubah. Adapun tantangan yang dihadapi dalam pembaruan sistem pendidikan pesantren yaitu tantangan secara makro dan mikro. Secara makro 
pesantren ditantang untuk menggarap triumvirate kelembagaan, yakni keluarga, lingkungan kerja, dan pesantren sendiri. Sedangkan secara mikro, pesantren dituntut untuk menata ulang interaksi antara santri dan kiai, konsep pendidikan, dan kurikulum yang digunakan.

Keywords: reform, education, Pesantren

DOI: http://dx.doi.org/10.24239/jsi.v14i1.454.37-58

\section{Introduction}

Education is essentially an effort to humanize human beings. Human is a whole and complex person, so it is difficult to learn completely. Therefore, the problem of education will never finish, because human beings always evolve to follow the development of time.

Education has a strategic and important value in the survival of a nation. Education aims to develop intellectual, moral, and social capacities of students in order to live independently as the individuals and social beings.

In the Law of the Republic of Indonesia Number 20 Year 2003 regarding National Education System Article 3, it is mentioned that:

National education functions to develop the ability and form the character and civilization of dignified nation in order to educate the life of the nation, and aims to develop the potential of learners to become human beings who have faith and religious devotion to God Almighty, noble, healthy, knowledgeable, capable, creative, independent, and become a democratic and responsible citizen. ${ }^{1}$

This objective of education is certainly not separated from the goal of Islamic education as a religion of the majority of Indonesian people. It is based on the Q.S. al-Żāriyāt (51): 56:

${ }^{1}$ Republik Indonesia, Undang-Undang Nomor 20 Tahun 2003 Tentang Sistem Pendidikan Nasional, 4th ed. (Jakarta: Sinar Grafika, 2011). 7. 
"And I did not create the jinn and mankind except to worship Me."

The verse indicates that the purpose of the creation of man is to serve God Almighty. One of the media to know how to serve God Almighty is through education.

Currently, education is paid a serious attention by society. Deviant behavior that occurred among students and adolescents generally encourage society to question the effectiveness of the implementation of education in schools. Therefore, reform of the educational system and the objective of education is necessary. As it is known that a society is always dynamic, they develop and change from time to time so that renewal of educational goals is inevitable. Renewal of educational goals is intended to reform various plans and activities so that the educational process does not lose relevance to the demands of society, whether local, national, regional or global. ${ }^{2}$

One characteristic of a society is continuous development. People always experience change and development in various fields of life, especially science and technology; therefore, changes rapidly happen. Such changes occur almost in all aspects of life such as politics, economics, ideology, education, ethical and aesthetic values. The changes that occur affect the development of each individual, for example, in terms of skills, attitudes, aspirations, interests, spirit, habits, and even lifestyle.

Abraham Maslow says that change is caused by motivation. ${ }^{3}$ Psychologically, a motivated man will increase his work activity. ${ }^{4}$ This means, it is motivation that makes people perform activities globally.

${ }^{2}$ Bahaking Rama, Jejak Pembaruan Pendidikan Pesantren Kajian Pesantren As'adiyah Sengkang Sulawesi Selatan (Jakarta: Parodataman Wiragemilang, 2003). 32.

${ }^{3}$ Abraham Maslow, Motivasi Dan Kepribadian, 2nd ed. (Jakarta: Pustaka Binamas Pressindo, 1994). 31.

${ }^{4}$ John. B. Miner, Theories of Organization Behavior (America: The Dryden Press, Hinsdale Illinois, 1980). 19. 
One form of anticipation to global development and change is to prepare community members to deal with and overcome the complexities of development, changes and challenges. In this context, the idea of educational reform becomes very important as an effort to deal with the dynamics of development that occurs in society. ${ }^{5}$

Today, society is so intense to face changes in mindset, lifestyle, daily needs and future life. Such conditions greatly affect the standards of community life. They, inevitably, must try to think and be progressive in response to the developments and demands of the times.

One of the efforts to respond to the development and demands of the times is to reform education. Pesantren, as the oldest Islamic educational institution, has undergone developments and reform, including system of education. Changes and developments in the educational system of pesantren is necessary to respond to changes of time. The classification of pesantren into salafiah (traditional) and khalafiah (modern) is a fact that cannot be denied. This is because institution of pesantren is not much different from other educational institutions that always follow the development of time. $^{6}$

Pesantren as a large educational institution that widely spread in the country has contributed to the formation of a religious Indonesian man. This institute has given birth to many national leaders in the past, now and apparently also in the future. Many pesantren graduates take active participation in nation building. ${ }^{7}$ Therefore, it can be said that pesantren can be

${ }^{5}$ Rama, Jejak Pembaruan Pendidikan Pesantren Kajian Pesantren As'adiyah Sengkang Sulawesi Selatan. 18.

${ }^{6}$ Ibid. 124.

${ }^{7}$ Ibid. 126. 
regarded as one of the Islamic educational institutions that has much contributed to society.

In addition to the oldest Islamic educational institution in Indonesia, pesantren also has contributed positively to the development of qualified and Islamic human resources for education in Indonesia. Pesantren served as an institution to spread and study Islam. The ability of pesantren is not only in the personal development of Muslims, but in the effort to organize social change. The influence of pesantren is not only seen in the life of students and alumni, but also covers the lives of surrounding communities. Pesantren as an integral part of the national educational system means that Islamic education is also regulated in the national educational system. ${ }^{8}$ Based on this description, it can be concluded that existence of pesantren gives benefits for the development of Human Resources (HR).

Pesantren is the only educational institution that is resistant to the various waves of modernization, ${ }^{9}$ and it still survive to this day. Since modernization in Islamic education occur, not many traditional Islamic educational institutions such as pesantren are able to survive. Most disappeared after being displaced by the expansion of the public and secular educational system. ${ }^{10}$ Due to collisions throughout history, Muslims today seem to be a lost generation. Islamic-labeled education, such as pesantren and madrasah, is still considered second-class education. This condition causes many Muslim intellectuals to apply the concept of modernization in Islamic education, which is mastering religious and secular sciences so as to compete in the international arena. Then these progressive and innovative values

${ }^{8}$ Syafaruddin, Manajemen Lembaga Pendidikan Islam, 1st ed. (Jakarta: Ciputat Press, 2005). 210.

'Suwendi, Sejarah dan Pemikiran Pendidikan Islam (Jakarta: Raja Grafindo Persada, 2004). 157.

${ }^{10}$ Azyumardi Azra, Pendidikan Islam Tradisi dan Modernisasi Menuju Millenium Baru (Ciputat: Logos, 1999). 130. 
are adopted as a strategy to catch up with other educational models. $^{11}$

Based on the above description, it is said that through the efforts made by the scholars, pesantren is able to face various challenges, both internal and external, so that pesantren still survive and can compete and stand together with modern educational system.

Based on this background, the main issue to be addressed in this paper is, how is the reform of educational system in Pesantren?

\section{The Basic Concept of Reform of Pesantren's Educational System}

In dictionary, there are many words that refer to this Indonesian term "pembaharuan", such as renewal, innovation, reorganization, reform, modernization. ${ }^{12}$ The meaning of the term "pembaharuan", quoted by Bahaking Rama, ${ }^{13}$ is as follows:

- Cece Wijaya said that reform is a new change, and different from the things that have existed before and deliberately attempted to improve the ability in order to achieve certain goals.

- Abu al-A'la al-Mawdudi said that reform is a work of liberation from the tradition of ignorance by using various means available to purify the deeds from the elements of ignorance.

- The Indonesian Ulema Council argued that reform is a courage to arouse the stability that has taken place.

In short, it can be concluded that reform is something that is done effectively, efficiently, and productively toward progress.

\footnotetext{
${ }^{11}$ Ibid. 7-8.

${ }^{12}$ John M. Echols and Hassan Shadily, Kamus Inggris Indonesia (Jakarta: Gramedia, 1996). 449.

${ }^{13}$ Rama, Jejak Pembaruan Pendidikan Pesantren Kajian Pesantren As'adiyah Sengkang Sulawesi Selatan. 20-21.
} 
Regarding the term system, W.J.S. Poerwadarminta said that the system is a regular method to do something. ${ }^{14}$ While the term tarbiyyah is derived from the word rabba which means to grow, develop, preserve, care for, maintain its sustainability or existence. ${ }^{15}$ Tarbiyyah can be derived from three words: 1) Rabayarbü-tarbiyyah, which means "to grow and develop"; 2) Rabiyayarbā-tarbiyyah, which means "to grow and develop"; 3) Rabbayarubbu-tarbiyyah, which means "improving, controlling, preserving, caring, beautifying, organizing and preserving." 16

The term pesantren, in Kamus Besar Bahasa Indonesia, comes from the word "santri". Pesantren means dormitory where students learn to study Islam, or it can be called pondok, ${ }^{17}$ while santri are people who study Islam. ${ }^{18}$ Bahaking Rama cited Johns' opinion who argued that pesantren comes from the word "Tamil", which means "teachers". ${ }^{19}$ Muljono Damopolii quoted C.C. Berg's opinion said that the term comes from shastri which means "people who know the holy books of Hinduism". ${ }^{20}$

Pesantren is defined as a traditional Islamic educational institution to study, understand, deepen, live, and practice the teachings of Islam by emphasizing the importance of religious morality as a guideline of everyday behavior. It should be pointed out that the traditional in this definition does not mean oldfashioned and obsolete, but it refers to the sense that this

\footnotetext{
${ }^{14}$ W.J.S. Poerwadarminta, Kamus Umum Bahsa Indonesia (Jakarta: Balai Pustaka, 2007). 1134.

${ }^{15}$ Ibn 'Abdullāh Muhammad ibn Ahmad al-Anșārī al-Qurțūbī, Tafsìr AlQurtūbī, Vol. I (Kairo: Dār al-Sya'biy, n.d.). 120

${ }^{16}$ Abd. Rahman Al-Nahlawi, Prinsip-Prinsip Dan Metode Pendidikan Islam (Jakarta: CV. Diponegoro, 1992). 31

${ }^{17}$ Departemen Pendidikan Nasional, Kamus Besar Bahasa Indonesia, 1st ed. (Jakarta: Balai Pustaka, 2001). 866.

${ }^{18}$ Ibid. 997.

${ }^{19}$ Rama, Jejak Pembaruan Pendidikan Pesantren Kajian Pesantren As'adiyah Sengkang Sulawesi Selatan. 35.

${ }^{20}$ Muljono Damopolii, Pesantren Modern IMMIM: Pencetak Muslim Modern, 1st ed. (Jakarta: Rajawali Press, 2011). 56.
} 
institution has lived for hundreds of years ago and it has become part of the system of Muslims life in Indonesia. ${ }^{21}$

What is meant by the reform of the pesantren education system based on the opinions of experts as quoted by Bahking Rama is to make changes from the traditional mono leader system with halaqah learning system to the classical learning system that is managed by the organization collectively and deliberatively. The indicator of reform at least can be measured from the aspect of objectives, structure, materials, and mechanism to achieve the objectives of reform. ${ }^{22}$ Therefore, it can be concluded that reform of pesantren educational system is what should be done effectively, efficiently and productively toward the progress of pesantren education.

\section{Forms of Reform in Pesantren Educational System}

The system of education developed in pesantren can be seen from many aspects. First, In terms of subject matter, pesantren teaches religious subjects based on classical books. The capacity of one's knowledge is measured from the book he studied. Secondly, the method used in teaching is sorogan and wetonan. Sorogan is a method of teaching where students read the book in front of the kiai and the kiai listens and then corrected if they made mistakes. Wetonan is a method of teaching where the kiai reads the book in front of the santris and santris record both meaning and vowel. ${ }^{23}$ The term weton comes from the Javanese word wektu which means the time for learning is given at certain times, ie before and after obligatory prayer. In West Java, this

\footnotetext{
${ }^{21}$ Rama, Jejak Pembaruan Pendidikan Pesantren Kajian Pesantren As'adiyah Sengkang Sulawesi Selatan. 58.

${ }^{22}$ Ibid. 21.

${ }^{23}$ Haidar Putra Daulay, Pemberdayaan Pendidikan Islam di Indonesia, 1st ed. (Jakarta: Rineka Cipta, 2009). 125.
} 
method is called bandongan, halaqah in Sumatera. This system is also known as balaghah. ${ }^{24}$

The pesantren learning system was originally non-classical. Santris are not divided on a grade basis. The santris may sit in the same room but differ in the books they read. Promotion in class every year is not known. The height of one's knowledge is measured by the type of book they read. The management of education and certificate are not known. No certain limit of years for students to settle in pesantren. It is common for santris to move from a pesantren to another to seek the more specific knowledge possessed by kiai in that place, such as the expertise of Arabic, hadith, tafsir tasawuf and so forth. ${ }^{25}$ Based on this description, it can be argued that the pesantren learning system in the classical era is much different from the pesantren learning system in this modern era.

The lessons given in pesantren are religious subjects. In a education of pesantren, the main priority is Arabic-related knowledge such as sharf and nahw, and sciences associated with Islamic jurisprudence, the Quran, kalam, Islamic monotheism, morals and mysticism. ${ }^{26}$ It shows that the education and lessons that pesantren provided in the classical era tends to focus on the religious principles which are accompanied by various branches of sciences.

Pesantren as a religious educational institution is a reality that can not be denied. Throughout its history, pesantren continues to focus on this activity. In developing education, pesantren has shown endurance to pass through various ages with various problems for Muslims in this country.

${ }^{24}$ Marwan Saridjo, Pendidikan Islam Dari Masa ke Masa Tinjauan Kebijakan Publik Terhadap Pendidikan Islam di Indonesia, 1st ed. (Jakarta: Yayasan Ngali Aksara \& Penamadani, 2010). 46.

${ }^{25}$ Ibid. 38.

${ }^{26}$ Ibid. 42. 
The pesantren is able to contribute to the process of transmitting Islamic sciences, reproducing ulama, maintaining Islamic knowledge and tradition, and forming and expanding a community of santri. Pesantren has a significant influence among the community. In terms of curriculum, the development of pesantren can be divided into five patterns: ${ }^{27}$

Pattern I, the subject matter taught in this pesantren is religious subjects in classical books. The method is wetonan and sorogan, not classical system. The santris are assessed by the books they read. General subjects are not taught, and certifacte is not regarded important as a tool to find job. The most important thing is the deepening of Islamic sciences through the classical books.

Pattern II, it is almost the same as the first pattern. However, in the pattern II, learning activities are implemented in a classical and non-classical, as well as skills education and organization. In certain education, a little general knowledge is taught. Students are divided into levels of education starting from ibtidaiyah, tsanawiyah and aliyah. The method used is wetonan, sorogan, and memorization.

Pattern III, the subject matter is supplemented by general subjects and other training such as skill, boyscout, sport, art and organization education.

Pattern IV, the focus is on skill lessons besides religious lessons. Skills are intended to provide santris with victuals after graduation. The skills that have been taught include agriculture, carpentry, and animal husbandry.

\footnotetext{
${ }^{27}$ Ibid. 67-68.
} 
Pattern V, the subjcet matters that are thaught include:

- Classical books

- In addition to religious subjects, general subjects are also taught. Therefore, the curriculum used consists of the curriculum designed by the pesantren itself and that of the government by modifying religious subject matter.

- Skills are taught with various kinds of activities. ${ }^{28}$

As an educational institution, pesantren emerges and evolves from social experience of the community. In other words, pesantren has a close relationship to the community. This fact can be seen not only from the background of the establishment of pesantren in a particular environment, but also in maintaining the existence of pesantren itself through the provision of waqf (endowment), sadaqah (charity), hibah (grants), and so on.

Instead, pesantren generally gives reward to the surrounding community in various ways, not only in the form of providing educational and religious services, but also social, cultural and economic guidance for the community. So, with such conditions, pesantren lies at the hearts of society, and society give hope to the pesantren to solve a crisis in religious-social life, and to save generation. ${ }^{29}$

Based on the description, it can be understood that pesantren in terms of curriculum can be divided into five patterns and each pattern has a different curriculum model.

Pesantren is also expected to meet the aspirations of Muslims who want a balanced education between religious and general knowledge. That way, society will not be easily influenced by cultural values outside Islam which developed rapidly. To

${ }^{28}$ Daulay, Pemberdayaan Pendidikan Islam Di Indonesia. 65-66.

${ }^{29}$ Ibid. 67. 
realize it, pesantren tried to reform educational system in various aspects.

In the context of reform of Islamic education, Azyumardi Azra argues, as quoted by Bahaking Rama, that the idea of Islamic modernism which gain its momentum since the early twentieth century, in the field of education, is realized with the establishment of modern educational institutions. The point of departure of the modernization of Islamic education here is the institutional system of modern education. Pesantren educational system is indigenous education, which is modernized by adopting certain aspects of the modern educational system, especially in the content of curriculum, techniques and methods of learning. ${ }^{30}$

Referring to the above opinion, it can be said that the reform of the pesantren educational system can be seen from aspects of educational structure, curriculum content, and methodology.

Reform of the educational system in Indonesia occurred in the mid-19th century because it was developed by the Dutch colonial government. Azyumardi Azra said, quoted by Bahaking Rama, it is admitted that the earliest modernization of the educational system in Indonesia was not from Muslims. The first modern educational system, which in turn influenced the Islamic educational system, was introduced by the Dutch colonial government. This stems from the extension of the opportunity for natives in the 19th century to get education. This program was conducted by the Dutch colonial government by establishing a people's school or village school. The system introduced by the Dutch colonial government is a classical, which is different from the traditional Islamic education system with the system of halaqah. ${ }^{31}$

\footnotetext{
${ }^{30}$ Rama, Jejak Pembaruan Pendidikan Pesantren Kajian Pesantren As'adiyah Sengkang Sulawesi Selatan. 3.

${ }^{31}$ Ibid. 139.
} 
Along with public awareness that religious education is important, many pesantren make reform to their system of education. The reform can be seen as follows:

\section{Reform in Structure of Education}

Cece Wijaya, as quoted by Bahaking Rama, said that the structure of education includes planning, organizing, and managing facilities and infrastructure so that education as a whole system becomes more functional for the community, both individually and collectively. Educational planning is a series of ways to look at priorities, both economically, socio-culturally, and politically.

The reform in educational structure is concerned with improving the performance of its executors by improving all the elements involved in the education system for the achievement of predetermined objectives. ${ }^{32}$

Today, there are many pesantren buildings built with storeyed concrete, equipped with adequate educational facilities and infrastructure. The situation was never witnessed in the 1950s ago. This phenomenon shows that pesantren has undergone reform in educational system especially in the aspect of educational structure.

In addition, the reform in the aspect of educational structure can also be seen from changes in the institutional management system. The example is As'adiyah pesantren, it changes in terms of the institutional management system from the individual leadership of a kiai to the collective leadership under the foundation. ${ }^{33}$

Therefore, it can be said that the reform of the pesantren educational system can be seen from the change of leadership

${ }^{32}$ Ibid. 32.

${ }^{33}$ Ibid. 141. 
which has been traditionally held by a kiai into collective leadership under the foundation.

\section{Reform in curriculum}

Curriculum is derived from the Latin word "currere", that literally means "field of race". The field has the starting and finishing lines. In the field of education, teaching materials have been determined exactly, from where to start, how is the process, and when it ends. The curriculum also describes what experiences and exercises should be provided, and how to master the materials in order to achieve graduation. ${ }^{34}$ In terminological meaning, curriculum, as cited by Kunandar, ${ }^{35}$ is defined as follows.

- Alice Miel states that curriculum is all the experiences and educational influences gained by students in school.

- Harold B. Abertycs states that the curriculum is all activities both within and outside the classroom under the responsibility of the school.

- William B. Variety states that the curriculum is the whole program and life in school, ie all students' experiences under the responsibility of the school.

In line with the above opinion, the Government Regulation of the Republic of Indonesia Number 19 Year 2005 on National Education Standards states that

The curriculum is a set of plans and arrangements concerning objectives, content, lesson materials, and ways used as guidelines for the implementation of learning activities to achieve specific educational goals. ${ }^{36}$

\footnotetext{
${ }^{34}$ Syaiful Sagala, Supervisi Pembelajaran dalam Profesi Pendidikan, 1st ed. (Bandung: Alfabeta, 2010). 34.

${ }^{35}$ Kunandar, Guru Profesional Implementasi KTSP Dan Sukses Dalam Sertifikasi Guru, 6th ed. (Jakarta: Rajawali Press, 2010). 123.

${ }^{36}$ Republik Indonesia, Peraturan Pemerintah RI Nomor 19 Tahun 2005 Tentang Standar Nasional Pendidikan (Jakarta: Cermerlang, 2005). 11.
} 
Based in these definitions, it can be said that curriculum is a system consisting of several components that are interconnected and work together to achieve educational goal.

In the formal sense, education always has a written design that is arranged systematically, clearly, and in detail. The draft is a reference to implement the educational process in the world of education, which is commonly called curriculum. Curriculum plays a significant role to achieve goal in an educational institution. Therefore, curriculum reform is important in achieving expected educational objectives.

Nana Syaodih Sukmadinata, as quoted by Bahaking Rama, ${ }^{37}$ stated that reform of curriculum can be marked by the introduction of new subject that has not been previously taught. In addition, reform of curriculum can also be marked by change in time allocation, either in the form of addition or subtraction according to the needs of the contemporary era.

Since the beginning of independence, pesantren began to respond to the expansion of public educational system that had been spread by the government by extending the scope of their education. There are at least two ways in which pesantren respond to the expansion: First, revising the curriculum by incorporating more general subjects and skills; secondly, opening its institution and educational facilities for public education. ${ }^{38}$ This reality shows that pesantren has changed in educational system especially in curriculum. This is seen by the revision of curriculum in pesantren.

The reform in curriculum can be seen in several pesantren in Indonesia. In South Sulawesi, for example, there are some pesantren with modern labels that have revised their curriculum,

\footnotetext{
${ }^{37}$ Rama, Jejak Pembaruan Pendidikan Pesantren Kajian Pesantren As'adiyah Sengkang Sulawesi Selatan. 34.

${ }^{38}$ Mujamil Qomar, Pesantren Dari Transformasi Metodologi Menuju Demokratisasi Institusi (Jakarta: Gelora Aksara Pratama, 2005). 78.
} 
such as Modern Pesantren IMMIM Makassar, Modern Pesantren Dar al-Arqam Gombara Makassar, and Modern Pesantren Datuk Sulaiman Palopo. In general, these modern pesantrens adopted government's curriculum by adding the content of religious subjects such as Islamic law (figh), Arabic, Islamic monotheism ('aqidah), the Quran and Hadith. ${ }^{39}$

Based on this, it can be understood that reform in curriculum in Indonesian Pesantrens, especially in South Sulawesi, can be seen in the change in subject matters.

\section{Reform in methodological aspects}

In the course of time, new awareness emerged from pesantren leaders. The constantly changing social, cultural, economic, and political demands unveil the hindrances of kiai and teachers and force them to immediately develop pesantren education including methodological aspects.

Reform of methodology is rooted in the fact that there is no better and effective teaching method because each method has its advantages and disadvantages. Therefore, the learning method tends to develop so that the method used can realize the purpose of education well. ${ }^{40}$

New ideas entering into the field of education can change the existing traditional educational system. The non-classical system turns into a classical one. The methods of teaching used by teachers are no longer solely based on the methods of sorogan, wetonan and memorization, but varied according to the demands of the classical system.

The sorogan and wetonan (bandongan) methods have shifted and changed into lectures although they are not a

\footnotetext{
${ }^{39}$ Syamsuddin Arif, Jaringan Pesantren Di Sulawesi Selatan. (Jakarta: Badan Litbang and Diklat Departemen Agama RI, 2008). 196.

${ }^{40}$ Rama, Jejak Pembaruan Pendidikan Pesantren Kajian Pesantren As'adiyah Sengkang Sulawesi Selatan. 34.
} 
consensus of teachers in pesantren. The sorogan and wetonan methods that characterize some pesantren have been replaced by lecturing methods as a basic teaching method with a classical system. ${ }^{41}$

Implementation of learning at pesantren found a change in various teaching methods. This diversity proves that pesantren has made serious adjustments through the horizontal addition, thereby further diluting its boundaries with Western model learning systems. The pesantren leaders today have practiced very diverse methods, such as methods of demonstration, questioning, discussion, and so on. ${ }^{42}$ This reality indicates that pesantren educational institutions have experienced a reform and modernization in educational system especially in the aspects of learning methods.

\section{Impacts and Challenges in the Reform of Pesantren's Educational System}

The reform of the pesantren's educational system undergoes a certain historical process. At the beginning of the 20th century, pesantren education system began to be developed in line with the demands of society. Starting in 1970s, there was a considerable change in the pesantren's educational system. If previously educational system in pesantren is non-school education system (traditional bandongan class), school-based education system comes later. If initially pesantren was managed traditionally, now it is carried out with modern system such as religious school developed by Ministry of Religious Affairs. This is fundamentally different from the national educational system. Salafi pesantren is not much more, but large pesantrens have developed into khalafi pesantren, such as those that include general subjects in accordance with a national educational

\footnotetext{
${ }^{41}$ Qomar, Pesantren Dari Transformasi Metodologi Menuju Demokratisasi Institusi. 145.

${ }^{42}$ Ibid. 151.
} 
system. While small salafi pesantrens that survive are less able to develop in a conducive way. ${ }^{43}$ Therefore, not many pesantrens have adopted formal education system as managed by the government.

The combination of the traditional and the formal education systems is one of the causes of the reform of the pesantren education system that has weaknesses and advantages. The weakness is to make pesantren increasingly experience a identity crisis. On the one hand, pesantren still has social character, because it have lasted for centuries, at least in extracurricular learning in the form of pengajian, and on the other hand, the tendency to cultivate elitist-style education is also going strong. The identity crisis is due to the difficulty of reconciling these two conflicting characters, and until now it has not been resolved yet.

In addition, reform of the pesantren's educational system through the adoption of the formal education system reduces the independence of pesantren. The pesantren must follow the standards set by the government. For example, pesantren no longer makes its own curriculum, but follows curriculum designed by the Ministry of Religious Affairs. Another weakness is the emergence of economic orientation among pesantren that can reduce the sincerity of santri while studying in pesantren. The santris may expect to obtain a diploma as a ticket to obtain a certain position or occupation in the future, as it is the case with the students in the school in general. ${ }^{44}$ Therefore, the reform is not always considered positive, but there are certain aspects of the reform that are considered negative.

Nowadays, the reform of the pesantren's educational system begins to be considered from multi perspective so it is not always considered negative. There are weaknesses of the reform that

${ }^{43}$ Ibid. 79.

${ }^{44}$ Ibid. 82 . 
must be criticized, but there are also certain advantages that need to be copied and even developed.

The advantages include that pesantrens have ability to survive in the midst of changes and competition, ability to improve quality, and ability to grow and adapt to the changing era. $^{45}$ Therefore, rapid changes and developments awaken pesantrens to perform actions that provide benefits for the continuity and development of Islamic education.

One anticipation to global development and change is to provide society's member to deal with and solve all the complexities of challenges. ${ }^{46}$

The development of science and technology, spread of information, and cultural encounter can influence on the society's trend to think rationally and behave adaptively. They were faced with new interesting and tempting options to take. The current society have intensively confronted changes in frame of thought, way of life, daily needs, and future life. This condition has certainly given impact to standard of community's life. They, willing or not, always think and behave progressivel as a respons to development and demands of time. This form of response needs to be taken into consideration by the pesantren.

Today, society's trend has changed a lot, although the output of the pesantren do not change. The main problems does not lie on the potential of pesantren's graduates, but on the shift of measure. At the present time, what becomes a standard measure is the issues that relate to social, modern organization, pluralism of science, and so forth. These issues in the past were not addressed at all in the pesantren education. Today, the pesantren deals with new challenges which include reform of educational system.

\footnotetext{
${ }^{45}$ Ibid. 77.

${ }^{46}$ Rama, Jejak Pembaruan Pendidikan Pesantren Kajian Pesantren As'adiyah Sengkang Sulawesi Selatan. 18.
} 
At the macro level, pesantren is challenged to work on triumvirate institution, namely family, work environment, and pesantren itself, while at the micro level, pesantren is required to rearrange the interaction between santris and kiai, educational concept, and curriculum. ${ }^{47}$ Therefore, both challenges must be responded by the pesantren through strategic steps so that it can bring satisfying results.

\section{Conclusion}

The basic concept of reform is in order the pesantren education system make an effective, efficient and productive change leading to the advancement of pesantren education. The forms of reform can be viewed from various aspects including educational structure, curriculum, and methodological aspects.

The impact of reform can be seen from negative and positive aspects. From negative aspect, salafi pesantren is less able to develop, and khalafi pesantren begins to economicoriented which implies a lack of the values of sincerity. While the positive aspects include that pesantren has the ability to survive in the midst of constant change and competition, to improve their quality, and to develop and adapt to the ever changing demands of time. The challenges faced in the renewal of the pesantren education system are at the macro and micro levels. At the macro level, pesantren is challenged to work on triumvirate institution, namely family, work environment, and pesantren itself, while at the micro level, pesantren is required to rearrange the interaction between santris and kiai, educational concept, and curriculum.

\section{References}

Arif, Syamsuddin. Jaringan Pesantren di Sulawesi Selatan. Jakarta: Badan Litbang and Diklat Departemen Agama RI, 2008.

Azra, Azyumardi. Pendidikan Islam Tradisi dan Modernisasi

\footnotetext{
${ }^{47}$ Qomar, Pesantren Dari Transformasi Metodologi Menuju Demokratisasi Institusi. 76.
} 
Menuju Millenium Baru. Ciputat: Logos, 1999.

Damopolii, Muljono. Pesantren Modern IMMIM: Pencetak Muslim Modern. 1st ed. Jakarta: Rajawali Press, 2011.

Daulay, Haidar Putra. Pemberdayaan Pendidikan Islam di Indonesia. 1st ed. Jakarta: Rineka Cipta, 2009.

Departemen Pendidikan Nasional. Kamus Besar Bahasa Indonesia. 1st ed. Jakarta: Balai Pustaka, 2001.

Echols, John M., and Hassan Shadily. Kamus Inggris Indonesia. Jakarta: Gramedia, 1996.

Kunandar. Guru Profesional Implementasi KTSP dan Sukses dalam Sertifikasi Guru. 6th ed. Jakarta: Rajawali Press, 2010.

Maslow, Abraham. Motivasi dan Kepribadian. 2nd ed. Jakarta: Pustaka Binamas Pressindo, 1994.

Miner, John. B. Theories of Organization Behavior. America: The Dryden Press, Hinsdale Illinois, 1980.

al-Nahlawi, Abd. Rahman. Prinsip-Prinsip dan Metode Pendidikan Islam. Jakarta: CV. Diponegoro, 1992.

Poerwadarminta, W.J.S. Kamus Umum Bahsa Indonesia. Jakarta: Balai Pustaka, 2007.

Qomar, Mujamil. Pesantren dari Transformasi Metodologi Menuju Demokratisasi Institusi. Jakarta: Gelora Aksara Pratama, 2005.

al-Qurțūbī, Ibn 'Abdullāh Muḥammad ibn Aḥmad al-Anșārī. Tafsīr Al-Qurtūbī. Vol. I. Kairo: Dār al-Sya'biy, n.d.

Rama, Bahaking. Jejak Pembaruan Pendidikan Pesantren Kajian Pesantren As'adiyah Sengkang Sulawesi Selatan. Jakarta: Parodataman Wiragemilang, 2003.

Republik Indonesia. Peraturan Pemerintah RI Nomor 19 Tahun 2005 Tentang Standar Nasional Pendidikan. Jakarta: 
Vol. 14, No. 1, Juni 2017: 37-58

Cermerlang, 2005.

Republik Indonesia. Undang-Undang Nomor 20 Tahun 2003 Tentang Sistem Pendidikan Nasional. 4th ed. Jakarta: Sinar Grafika, 2011.

Sagala, Syaiful. Supervisi Pembelajaran dalam Profesi Pendidikan. 1st ed. Bandung: Alfabeta, 2010.

Saridjo, Marwan. Pendidikan Islam dari Masa ke Masa Tinjauan Kebijakan Publik Terhadap Pendidikan Islam di Indonesia. 1st ed. Jakarta: Yayasan Ngali Aksara \& Penamadani, 2010.

Suwendi. Sejarah dan Pemikiran Pendidikan Islam. Jakarta: Raja Grafindo Persada, 2004.

Syafaruddin. Manajemen Lembaga Pendidikan Islam. 1st ed. Jakarta: Ciputat Press, 2005. 